\title{
Plant Protection Practices Adopted by Brinjal Farmers - A Diagnostic Study
}

\author{
J. Kavipriya ${ }^{1 *}$ and M. Senthil Kumar ${ }^{2}$ \\ ${ }^{1}$ Department of Agricultural Extension and Rural Sociology, Agricultural college and \\ Research Institute, Madurai, TN, India \\ ${ }^{2}$ Directorate of Extension Education, Tamil Nadu Agricultural University, \\ Coimbatore, TN, India \\ *Corresponding author
}

\section{A B S T R A C T}

Keywords

Adoption and plant protection practices

Article Info

Accepted:

07 January 2021

Available Online:

10 February 2021
Brinjal is the one of the major vegetable crop grown in Tamil Nadu and the crop is grown throughout the year. Brinjal is one among the crop which consumes more chemicals for management of pest and diseases. The farmers are convinced about the predictable level of controlled achieved with pesticides. Though pesticides have contributed for management of pest, there is a growing concern about indiscriminate use of pesticides in agriculture that resulted in health issues, destruction of beneficial insects, pesticide residues and environmental pollution. Keeping this in view, the study was carried out with 120 farmers from Thalaivasal and Gangavalli blocks of Salem district, Tamil Nadu. Salem district is purposively selected as it is one among the major brinjal growing areas in the state. Thalaivasal and Gangavalli blocks were selected based on more area under brinjal cultivation. Data collected through pre-tested interview schedule. The results of the study revealed that most of the farmers were found to have medium to high level of adoption on brinjal plant protection practices. Majority of the farmers resort to chemical, mechanical method of control and only 15 percent of the farmers adopt biological control methods.

\section{Introduction}

Vegetables play an important role in balanced nutrition. In India, the area of vegetable cultivation is increased from 55.93 Lakh ha in 1992 to 93.96 Lakh ha in 2014 (NHB, 201415). In Tamil Nadu, out of about 8.90 lakh ha of horticultural crops, vegetable crops are grown in 2.34 lakh ha. (TANHODA, 2015). Among the major vegetable crops, brinjal is one among the crops, which consumes more of chemicals for management of pest and diseases. Tamil Nadu ranks first in demand of pesticides in India (Pesticide and documentation unit, 2010). In modern agriculture, plant protection is considered to be the key to prospective and assured returns to investment. Norman Borlaug (1972) indicated that a complete ban on pesticide use in agriculture might result in 50.00 per cent reduction in crop production and 4-5 folds increase in food prices. Though pesticides 
have contributed for management of pests and resulted in increasing the yield of the crop, there is growing concern about indiscriminate use of pesticide in agriculture. The agricultural scientists and extension functionaries are creating awareness on adoption of Integrated Pest and Disease Management practices, it is found to be low among the farmers due to varied reasons. The present study was undertaken with the objective to study the characteristics of farmers and to document the adoption level of recommended plant protection practices.

\section{Materials and Methods}

Salem district of Tamil Nadu was purposively selected as it is one among the major brinjal growing districts. Thalaivasal and Gangavalli blocks of Salem district were selected based on more area under brinjal cultivation,(132 ha in Talaivasal block and 112 ha in Gangavalli). Sample size of 120 farmers was randomly selected for the study. Nine independent variables were selected on discussion with scientist and extension officials. Data was collected with well-structured interview schedule and analyzed with suitable statistical tools.

\section{Results and Discussion}

The findings and discussion of the study presents the adoption level of farmers with reference to the recommended plant protection practices. The adoption behaviour of farmers categorized into low, medium and high are given in Table 1.

The study revealed that majority 75.80 per cent of the farmers were having medium level of adoption followed by high $(13.30 \%)$ and low $(10.80 \%)$ levels. The reason for adoption might be due to better utilization of information sources like mass media exposure and extension agencies. The reason for low adoption level could be ascribed was that farmers might not have been convinced about the merits of plant protection technologies. The farmers with more economic resources could alone adopt more technologies. The farmers were aware of most of the practices, but they hesitate to adopt because of lesser interest and economic constraints, Anitha (1998).

\section{Practice-wise adoption level of farmers}

The plant protection management practices are broadly classified as cultural, mechanical, biological and chemical methods. The practice-wise adoption will provide a better understanding on the critical practices farmers follow or reject. The adoption level of the farmers on select practices is presented in Table 2.

\section{Cultural practices}

It could be inferred from the table 2 that among the cultural practices, the adoption rate is high for use of quality portray seedlings / certified seeds $(100.00 \%)$, summer ploughing (100.00\%), followed by avoiding excess use of water during diseases incidence $(98.33 \%)$, selection of varieties/hybrids (96.00 \%), avoiding overdose of nitrogen and phosphorous fertilizers $(93.33 \%)$ and destruction of crop residues and alternate crop plants $(83.33 \%)$. It indicates that the farmers are well aware of the above cultural practices and its impact on the crop yield and income and therefore, the adoption of cultural practices is high.

It is observed that no adoption was found with respect to soil solarization, less adoption was found on mulching (5.00\%), intercropping (5.83\%), recommended FYM and NPK fertilizers $(16.38 \%)$ and crop rotation (17.50 $\%)$. Though farmers are well aware of intercropping and crop rotation as they 
seldom follow, it might be due to lack of motivation, apprehension due to loss of monetary benefit due to change of crop. Emphasis may be given to the farmers through Information Education and Communication by extension personnel. High cost for soil solarization and labour cost involved for mulching might be the reason for less adoption of respective practices.

\section{Mechanical practices}

Majority $(89.16 \%)$ of the farmers removed the borer from damaged shoots and fruits; and 81.66 per cent of the farmers collect and destruct the egg masses, larvae and adults of severely damaged pest. 78.33 per cent of the farmers maintained their field weed free by timely weeding.

The reason for adoption of mechanical practices may be no cost involved in the practices, perceivable benefit by the farmer and easy to do as the brinjal crop is cultivated in manageable area by majority of marginal and small farmers. The mechanical practices may be encouraged by the extension machinery as it is not only low cost, but also liked by the farmers.

Less than one per cent $(0.83 \%)$ of the farmers use of yellow sticky traps for control of sucking pest. This might be due to the fact that majority of farmers resort to chemical methods of control and also the non availability of sticky traps in their vicinity.

\section{Botanical pesticides}

As the farmers mostly resort to chemical pest control, the use of botanical pesticide is found to be low. Less than one by fourth 24.20 per cent of the farmers sprayed neem oil to control whitefly. About 41.70 per cent of the farmers applied neem cake as basal dose at the time of land preparation for controlling root knot nematode infestation. It was observed that the use of botanical pesticides is on the increase for plant protection.

\section{Biological control}

None of the farmers used biological pest control practices like release of parasitoids against shoot and fruit borer and release of predators like lady bird beetles, green lace wing, etc. Only $(15.00 \%)$ of the farmers cultivate maize and pulses as border crop. None of the farmers adopt bird perches and release of Chrysoperlacarnea to control aphids. Lack of awareness and non availability of predators within the reach of farmers might be the reason for low / no adoption.

Table.1 Distribution of farmers according to their overall adoption of plant protection practices $(n=120)$

\begin{tabular}{|c|c|c|c|}
\hline S.No. & Category & Number & Per cent \\
\hline 1. & Low & 13 & 10.80 \\
\hline 2. & Medium & 91 & 75.80 \\
\hline 3. & High & 16 & 13.30 \\
\hline & Total & 120 & 100.00 \\
\hline
\end{tabular}


Table.2 Distribution of farmers according to their practice-wise adoption $(\mathrm{n}=120)$

\begin{tabular}{|c|c|c|c|}
\hline Packages & Recommended management practices & *Number & Per cent \\
\hline \multirow{12}{*}{$\begin{array}{l}\text { Cultural } \\
\text { practices }\end{array}$} & Selection of varieties/hybrids & 115 & 96.00 \\
\hline & Use of portray seedlings/certified seeds & 120 & 100.00 \\
\hline & Recommended FYM and NPK fertilizers & 20 & 16.38 \\
\hline & Crop rotation with sorghum & 21 & 17.50 \\
\hline & Intercropping with coriander and onion & 7 & 5.83 \\
\hline & Soil solarization to kill weeds, nematodes and insects & - & - \\
\hline & Deep summer ploughing & 120 & 100.00 \\
\hline & Avoiding over dose of nitrogen and phosphorus & 112 & 93.33 \\
\hline & Avoiding excess use of water during disease incidence & 118 & 98.33 \\
\hline & Mulching & 6 & 5.00 \\
\hline & Destruction of crop residue and alternate crop plants & 100 & 83.33 \\
\hline & Timely planting of seedlings & 94 & 78.33 \\
\hline \multirow{4}{*}{$\begin{array}{l}\text { Mechanical } \\
\text { practices }\end{array}$} & Destruction of egg masses, larvae and adults & 98 & 81.66 \\
\hline & Removal and destruction of damaged shoots and fruits & 107 & 89.16 \\
\hline & Use of yellow sticky trap for sucking pest & 1 & 0.83 \\
\hline & Weeding practices & 94 & 78.33 \\
\hline \multirow{2}{*}{$\begin{array}{l}\text { Botanical } \\
\text { pesticides }\end{array}$} & $\begin{array}{l}\text { Application of neem cake for controlling root knot nematode } \\
\text { and borer damage }\end{array}$ & 50 & 41.70 \\
\hline & Neem oil for sucking pest & 29 & 24.20 \\
\hline \multirow{5}{*}{$\begin{array}{l}\text { Biological } \\
\text { control }\end{array}$} & Release of parasitoids & - & - \\
\hline & Release of predators & - & - \\
\hline & Border cropping & 18 & 15.00 \\
\hline & Installation of bird perches & - & - \\
\hline & $\begin{array}{l}\text { Release of } 1^{\text {st }} \text { instar larvae (Chrysoperlacarnea) to control } \\
\text { aphids }\end{array}$ & - & - \\
\hline \multirow{2}{*}{$\begin{array}{l}\text { Biopesticides } \\
\text { and fertilizers }\end{array}$} & $\begin{array}{l}\text { Seed treatment with Trichoderma viridae or pseudomonas } \\
\text { fluorescence }\end{array}$ & - & - \\
\hline & Application of azospirillum or phosphobacteria & 26 & 21.66 \\
\hline \multirow{11}{*}{$\begin{array}{l}\text { Chemical } \\
\text { practices }\end{array}$} & Treating nursery bed with carbofuron to control nematode & 100 & 83.33 \\
\hline & Root dipping in dimethoate for control of little leaf of brinjal & 55 & 45.83 \\
\hline & $\begin{array}{l}\text { Application of pendimethalin or fluchloralin as pre } \\
\text { emergence herbicide }\end{array}$ & 26 & 21.70 \\
\hline & $\begin{array}{l}\text { Application of carbofuron in early stage of crop to avoid } \\
\text { sucking pest and nematode }\end{array}$ & 106 & 88.33 \\
\hline & Foliar spray of carbendazim to control early leaf spot & 11 & 9.16 \\
\hline & Application of copper fungicides to control wilt and spot & 44 & 36.66 \\
\hline & Installation of pheromone traps & - & - \\
\hline & Use of light traps & 20 & 16.66 \\
\hline & Foliar spray for micronutrient deficiency & 57 & 47.50 \\
\hline & Spraying of spiromesifen to control red spider mite & 65 & 54.16 \\
\hline & Spraying of clorantraniliprole for shoot and fruit borer & 57 & 47.50 \\
\hline
\end{tabular}


Table.3 Distribution of farmers based on recommended plant protection chemical used $(\mathrm{n}=120)$

\begin{tabular}{|l|l|c|c|}
\hline S. No & \multicolumn{1}{|c|}{ Category } & Number & Per cent \\
\hline $\mathbf{1 .}$ & $\begin{array}{l}\text { Recommended labeled chemicals and TNAU recommended } \\
\text { chemicals }\end{array}$ & 59 & 48.75 \\
\hline 2. & Non recommended chemicals & 61 & 51.25 \\
\hline & Total & $\mathbf{1 2 0}$ & $\mathbf{1 0 0 . 0 0}$ \\
\hline
\end{tabular}

Table.4 Recommended plant protection chemical dosages used by farmers $(n=120)$

\begin{tabular}{|c|l|l|l|l|l|}
\hline \multirow{2}{*}{ S.No } & \multirow{2}{*}{ Pesticide classes } & \multicolumn{2}{|c|}{ Recommended } & \multicolumn{2}{c|}{ More than recommended } \\
\cline { 3 - 6 } & & *Number & Per cent & *Number & Per cent \\
\hline 1. & Insecticides & 27 & 22.50 & 73 & 60.83 \\
\hline 2. & Fungicides & 22 & 18.33 & 78 & 65.00 \\
\hline 3. & Botanical Pesticides & 18 & 15.00 & 82 & 68.33 \\
\hline
\end{tabular}

(* Multi responses)

Table.5 Recommended chemicals adopted by farmers for pest and disease control in brinjal

\begin{tabular}{|c|c|c|}
\hline S. No & Major pest and disease & Chemicals used \\
\hline 1. & Shoot and fruit borer & $\begin{array}{l}\text { 1. Dimethoate } 30 \% \mathrm{EC} \\
\text { 2. Trizophos } 40 \% \mathrm{EC} \\
\text { 3. Trizophos } 35 \% \mathrm{EC} \\
\text { 4. Quinolphos } 20 \% \mathrm{AF} \\
\text { 5. Chlorpyriphos } 20 \% \mathrm{EC} \\
\text { 6. Lambalacyhalothrin } 5 \% \mathrm{EC} \\
\text { 7. Cypermethrin } 3 \%+\text { quinolphos } 20 \% \mathrm{EC} \\
\text { 8. Thiacloprid } 75 \% \mathrm{WP} \\
\text { 9. Chlorantraniliprole } 18.5 \% \mathrm{SC}\end{array}$ \\
\hline 2. & Red spider mite & $\begin{array}{l}\text { 1. Spiromesifen } 22.9 \% \mathrm{SC} \\
\text { 2. Dicofol } 18.5 \% \mathrm{EC}\end{array}$ \\
\hline 3. & White Flies & $\begin{array}{l}\text { 1. Thiamethoxam } 25 \% \text { WG } \\
\text { 2. Phosphamidon } 40 \% \text { SL }\end{array}$ \\
\hline 4. & Aphids and Jassid & $\begin{array}{l}\text { 1. Dimethoate } 30 \% \mathrm{EC} \\
\text { 2. Trizophos } 35 \% \mathrm{EC} \\
\text { 3. Quinolphos } 20 \% \mathrm{AF} \\
\text { 4. Phosphamidon } 40 \% \mathrm{SL} \\
\text { 5. Cypermethrin } 25 \% \mathrm{EC}\end{array}$ \\
\hline 5. & $\begin{array}{l}\text { Root knot and reniform } \\
\text { nematode }\end{array}$ & 1. Carbofuron $3 \% \mathrm{CG}$ \\
\hline 6. & $\begin{array}{l}\text { Bacterial wilt, Cercospora leaf } \\
\text { spot and Alternaria leaf spot }\end{array}$ & 1. Copper oxychloride \\
\hline 7. & Collar rot & $\begin{array}{l}\text { 1. Cymoxanil 8\%+ Mancozeb } 64 \% \text { WP } \\
\text { 2. Metalaxyl } 8 \%+\text { Mangozeb } 64 \% \text { WP }\end{array}$ \\
\hline
\end{tabular}




\section{Biopesticides and fertilizers}

None of the farmers adopt seed treatment and about 21.66 per cent of the farmers applied azospirillum in their field. As farmers are using seeds treated with chemicals/ seedlings from commercial nurseries, this practice was not followed.

\section{Chemical practices}

Majority 88.33 per cent of the farmers applied carbofuron in early stage of crop to avoid sucking pest and nematode, treating nursery bed with carbofuron to control nematode was followed by 83.33 per cent of farmers. No adoption was found on installation of pheromone traps and low adoption was found among farmers on foliar spray of carbendazim to control early leaf spot $(9.16 \%)$ and use of light traps $(16.66 \%)$.

The Universities and Central Insecticides Board and Registration Committee recommends chemicals for the plant protection. However, the farmers have access to chemicals of new molecules from various companies. The details of plant protection chemicals used by farmers are given in the table 3. It could be observed from the Table 3 that 51.25 per cent of the farmers were adopting chemicals, which were not recommended by Tamil Nadu Agricultural University and Central Insecticides Board and Registration Committee. The availability of new molecules from the companies and dealers might be the reason for using non recommended chemicals. The dosage recommendation for chemicals is prescribed for each chemical. The use of chemicals over and above the recommended dose or less than the recommended dose will highly influence the result of the pest control, besides lead to pest resurgence, toxicity and other environmental problems. The details of recommended plant protection chemical dosage used by farmers are given in Table 4 .
It is apparent from the Table 4 that only 22.50 per cent of the farmers were following recommended dosage of insecticides, fungicides $(18.33 \%)$ and botanical pesticides $(15.00 \%)$. Majority of the farmers have adopted dose that is more than the recommended, as the farmers thought that increase in dose might kill the pest quickly. The recommended chemicals adopted by farmers are given in the Table 5.

The above Table 5 shows that farmers adopted organophosphates to control chewing and sucking pest more than other synthetic insecticides in recommended quantity.

In conclusion the study has found that among the recommended practices, the farmers primarily resort to mechanical, cultural and chemical method of plant protection and they rarely adopt biopesticides and botanical control methods. This indicates that majority of farmers are not adopting Integrated Pest Management (IPM). Also, the study has observed that $51.25 \%$ of the farmers are using chemicals that are not recommended and $60.83 \%$ of the farmers adopt more that recommended dosage of insecticides and $65.00 \%$ of the farmers adopt more that recommended dose of fungicides. This would eventually result in indiscriminate use of pesticides and fungicides, and may have undesirable consequences in pest management, wastage of resources, environmental degradation and financial loss to the farmer. Extension efforts must be strengthened to improve the adoption level of recommended plant protection practices in brinjal cultivation among farmers.

\section{References}

Pesticide and Documentation Unit. 2010. Statewise Demand of Pesticides During the Last Five Years 2005-06 to 200910. Available at www.Indiastat.Com National Horticultural Board. 2015. All India 
Area, Production and Productivity of Vegetables in 2014-2015. Indian Horticultural Database. Available at www.nhb.gov.in.

TANHODA. 2015. Area, Production and Productivity of Horticultural Crops in 2015. Available at www.tnhorticulture.tn.gov.in

Anitha, S. 1998. Analysis of Pesticides and
Plant Protection Equipments Use Behaviour of Rice Yard Manure. Unpub. M.sc (Ag.) thesis, AC\&RI, TNAU, Coimbatore.

Borlaug, N.E., (1972). "Mankind and civilization at another crossroad in balance with nature-a biological myth" Bioscience 10(1):pp 41-47.

\section{How to cite this article:}

Kavipriya, J. and Senthil Kumar, M. 2021. Plant Protection Practices Adopted by Brinjal Farmers - A Diagnostic Study. Int.J.Curr.Microbiol.App.Sci. 10(02): 770-776.

doi: https://doi.org/10.20546/ijcmas.2021.1002.092 